\title{
Study of Distinctive Capabilities and Entrepreneurial Orientation on Return on Sales among Small and Medium Agro-Based Enterprises (SMAEs) in Malaysia
}

\author{
Amran Awang (Corresponding author) \\ Malaysian Entrepreneurship Development Center (MEDEC) \\ Universiti Technology MARA, Malaysia \\ Tel: 60-3-12-409-5407Ｅ-mail: amranawang@yahoo.com
}

Abdul Rashid Said Asghar

Faculty of Applied Science, University Technology MARA, Malaysia

Tel: 60-4-988-2000 E-mail: abdrashid@perlis.uitm.edu,my

Khairul Anwar Subari

Faculty of Business Management, University Technology MARA, Malaysia

Tel: 60-4-988-2000Ｅ-mail: nuar02500@gmail.com

\begin{abstract}
The human development report in 2003 of United Nation Development Program (UNDP) reveals that among others, economic reforms to establish macroeconomic stability is crucial for sustainable human development. The study aims to establish pertinent factors influencing performance of small and medium agro-based enterprises in northern states of Malaysia. The study utilizes 125 sample firms that operate in agricultural sectors. Direct and indirect effects of distinctive capabilities on entrepreneurial orientation (EO) and return on sales relationship among Malaysian agro-based entrepreneurs showed the development imperative.
\end{abstract}

Keywords: Entrepreneurship, Distinctive capabilities, Entrepreneurial orientation, Small and medium agro-based enterprise, Return on sales

\section{Background of the Study}

SMAEs are small and medium agro-based enterprises operates in northern Peninsular Malaysia with paid-up capital less than RM2.5 million, number of employees less than 150 and turnover less than RM75 million (Malaysia, 2006). SMAEs are producers, manufacturers, and/or provide services for agricultural business activities. SMAEs were organized in various legal forms such as proprietorship, partnership, private limited and limited companies.

Distinctive capabilities (DC) and entrepreneurial orientation (EO) are parts of strategic orientation concept (Andrew, 1963; Selznick, 1957). The strategic orientation of firms explained their sustainable competitive advantage and increased financial performance noted by Stevenson, Roberts and Grousbeck (1989). Moreover, Bettis and Hitt (1995) found DC and EO fostered uniqueness in firms to be ahead of others to survive in new competitive landscape. DC and EO are related where firms with higher EO levels owned wider variety of DC and predicted better performance (Smart \& Conant, 1994).

Firm's strategic orientation and competitive advantage were the focused issues among scholars in North America, Europe and Australasia countries. However, studies of those issues in Malaysian SMEs are at the infant stage (Awang \& Ahmad, 2005; Hashim, 2000). Small number of researches identified DC as firm's strategic orientation in Malaysian firms, when Hashim, Mohammad and Wafa (2001) noted that DC as a strategic orientation among Malaysian exporting firms. Moreover, entrepreneurship and resource studies in agro-based are called for due to agro-based sectors in Malaysia are becoming prominent with facilitating government policies in developing the industry (Malaysia, 2006).

Conceptually, firms are full of capabilities to enable them to produce and compete in the market (Barney, 1991). According to Hitt and Ireland (1985), effective integration of resources or capabilities in the firms is the DC that allows them to implement activities successfully. DC refers to the unique skills and activities a firm owned to be ahead of others (Selznick, 1957). Furthermore, DC fulfills valuable, rare, inimitable and organized resources 
(VRIO) (Barney, 1991). On the other hand, EO constitutes firm's entrepreneurial capabilities in innovativeness, proactiveness, risk taking, autonomy, and competitive aggressiveness that directly related to performance in Malaysian SMEs (Alvarez \& Barney, 2000; Awang, 2006; Lumpkin \& Dess, 1996). Covin and Slevin (1989) reiterated that strategic posture or EO is parts of organizational resources and capabilities.

Interrogations in resource-based view witnesses steady increment over the past years in determining the competitive advantage and performance of the firms. However, research has yet to establish the relationship between DC and EO and how they explain performance in Malaysian agro-based business firms.

\section{Problem Statement}

Most of the studies in core competencies are geared toward larger firms, few studies were found to explore core competencies in smaller firms, whereas smaller firms tend to be significant players in global market sometime performing better than bigger counterparts (Hitt, Ireland \& Hoskisson, 2003). The quest for specific answer of how many distinctive capabilities should be present in small firms, relevant to their main activities in order to be competitive.

Distinctive capabilities were crucial to guide small firms for higher performance (Hitt \& Ireland, 1985), however other studies found that EO explained performance better (Lumpkin \& Dess, 1996, 2001; Wilklund, 1998). The inquiry to the problem will determine to what extent of EO relates to distinctive capabilities and how they relate to performance.

\section{Literature Review}

Distinctive capabilities constitute firm's integrated bundle of skills and technologies, which are unique with knowledge driven and behavioral routines contributing to competitive advantage (Prahalad \& Hamel, 1990). Kuratko and Welsch (2002) reiterated that distinctive competencies developed through entrepreneurial process such as opportunity recognition, creative process and innovation.

Firm's capabilities or distinctive competencies concept is not new, developed in the early 1980s when Snow and Hrebiniak (1980), and Hitt and Ireland (1985) established the term. Similar terms and concept used are such as, core or organizational competencies, firm-specific competence, resource deployments, and invisible assets (Pavitt, 1991; Prahalad \& Hamel, 1990; Hayes, Wheelright \& Clark, 1988; Itami \& Roehl, 1987; Hofer \& Schendel, 1978).

Rumelt (1994) characterizes firm's core competencies into four aspects. First, those elements within corporate span support specific products or businesses. Second, competencies are temporal dominance where they are more stable and evolve slower than products. Third, competencies are developed through continuous practice. Fourth, it is the superficial expression of a deeper competition over competencies.

Studies by Miller and Friesen (1982), Miller (1983, 1987, \& 1988) developed firm-level entrepreneurship and its correlation to environment and organization sparked more study that is similar. Firm-level entrepreneurship revived entrepreneurial studies, which is almost reaching dead end (Gartner, 1985) when the scope of the study extended to general and strategic management aspect.

The concept has set the pace of new entrepreneurship paradigm in the $21^{\text {st }}$ century when Babson College starts its entrepreneurial orientation (EO) program in 2003 and EO becomes common term in Entrepreneurial, Management and Strategic Management Journals. EO known as the concept of firm's behavior engaging in innovativeness, proactiveness and risk taking (Miller, 1983) added with autonomy and competitive aggressiveness (Lumpkin \& Dess, 1996) also known as corporate entrepreneurship (Zahra, 1995). EO predicted higher performance among smaller firms produced consistent findings since early 90s found in Brown (1996), Dess et al. (1997), Wilklund (1998, 1999), Lumpkin and Dess (2001), Kreiser, Marino and Weaver (2002), and Wilklund and Shepherd (2003).

The literature proposes DC and EO as better determinants of the performance, thus more research is required to aid entrepreneurs and government identify appropriate measures.

The study underlines gaps in the literature that DC and EO in agro-based industry showed lack of concern among researchers (cf. Hashim et al., 2001). Studies in developed countries remain active to produce concrete findings in establishing dimensions and relationship of the variables (Lumpkin \& Dess, 1996; Lyon et al., 2000). Furthermore, increasing number of the studies were found explore on sample across national boundaries (e.g. Kreiser et al., 2002).

\section{Theoretical Framework and Hypothesis}

The underpinning theory that governs the study is the resource-based view (RBV). This is due to the variables under studies link the tangible and intangible resources inherent within small-scaled firms (Barney, 1991; 
Wernerfelt, 1984). RBV states that firm's resources possessed certain characteristics such as valuable, rare, inimitable, and non-substitutable resources (Barney, 1996). These resources were heterogeneous due to different firm possessed different characteristics of resources (Alvarez \& Barney, 2000). All resources with the identified characteristics became the firm's sustainable competitive advantages and might lead to superior firm performance. Andrew (1963) and Selznick (1957) used strategic orientation to explain the relationship between firm's strategy and performance. The strategic orientation constitutes distinctive capabilities identified as managerial orientation, which help to explain firm's performance (Hitt \& Ireland, 1985, Stevenson, et al. 1989). Other parts of strategic orientation are EO, as coined by Miller (1983). The theoretical framework of the research postulate EO and DC as the critical internal resources that enhance firm's performance. The theoretical framework is shown in Figure 1.

\subsection{Hypothesis}

Heterogeneity of resources led to multidimensionality of the dimensions of the independent and mediating variables in the study (Alvarez \& Barney, 2000). Lumpkin and Dess (1996) claimed that each EO dimensions should vary to each other, fortunately, the claim proved in Lumpkin and Dess (2001) and Kreiser et al. (2002). Therefore, we posited:

\section{H1: EO dimensions are independent from each other.}

H2: DC dimensions are independent from each other.

EO and DC are internal resources of the firm. EO formed the entrepreneurial capabilities should be related to DC which, formed the firm's resources and competencies (Covin \& Slevin, 1991). Therefore, we posited:

\section{H3: EO positively related to $D C$}

According to Hitt and Ireland (1985), DC predicted higher performance. Similarly, EO predicted higher performance. Furthermore, Khandwalla (1977) posited that strategic variable posed direct relationship to performance; however, Covin and Slevin (1991) proposed organizational resources and competencies facilitate and/or mediate EO performance relations. Therefore, we posited:

\section{H4: DC positively related to performance}

\section{H5: EO positively related to performance}

H6: DC mediates relationship between EO and performance

\section{Research Design and Methodology}

\subsection{Respondents}

Agro-based business firms selected for the study are those firms situated in the state of Kedah in the northern tip of Malaysian peninsular, which represented the agriculture state of the country. Firm's activities vary according to categorization proposed by Hashim (2000). The owner or top management who responds to the questionnaire represents the selected firms.

Firms selected from members registered with the Regional Farmers' Association or PPK, Muda Development Authority (MADA), Agricultural Bank and other agricultural association in the country.

\subsection{Survey Procedures}

Common method variance and social desirability bias was addressed to ascertain high response rate and quality (Ones, Reiss \& Visweravan, 1996; Podsakoff \& Organ, 1986). Ten firms pre-tested the survey instrument and found no problem in answering all the questions. A survey booklet with a cover letter and a postage paid return envelopes sent to 400 randomly selected agro-based firms in the state of Kedah. The random number table used to select from the list of PPK members who owned a business or firm. The list obtained from each of the PPK offices located throughout Kedah. After one month of non-response and partial responses, three research assistants visited the firms identified to collect the questionnaires after giving prior notices. Finally, we managed to collect 125 questionnaires, which made up $35 \%$ response rate.

\subsection{Research Instrument}

Distinctive capabilities adopted from Hitt and Ireland (1985) with 55 items in seven subsections. EO adopted from Khandwalla (1977), Miller (1983) and Shane et al. (1995) with modification according to Miller and Friesen (1982) and Lumpkin and Dess (1996). The number of items for EO is 29 items. The dependent variable computed from average on sales data, assets and capital covering the year 2000 to 2003. The questions was 
structured using a 7-point Likert Scale format where for DC, "1" - Not important at all and "7" - Very important, as for EO, "1" - Strongly disagree and "7" - Strongly agree.

Demographic data was analyzed at two levels; (1) Individual demographic, and (2) Firms demographic. The items under individual demographic were: gender, educational level, age, and status of the firm. Under the firm's level, the items were: types of business, forms of business registration, and duration of operation. Firm demographics of business types and forms used as control variables to ascertain their impact on the variables studied.

\section{Findings and Discussions}

\subsection{Data analysis and Hypothesis Testing}

A two-steps analysis used to segregate the data according to their different perspectives to help simplify more advance analysis in the following steps. Step 1 was observed using factor analysis where the Principal Component Analysis (PCA) and Varimax Rotation to identify the underlying dimensions of DC and EO. Each of the identified variables analyzed separately and reproduced two different tables. For control variables, the researchers identified three control variables found significantly interacted on EO performance relationships in previous researches (Dess, et. al., 1997; Kreiser et al., 2002; Lumpkin \& Dess, 2001; Wilklund, 1998; Wilklund $\&$ Shepherd, 2003). The control variables were the duration of operation, types of business, and registration status. As for the duration of operation, the control variable was dummy coded, "1" - More than 10 years of operation, "0" - Less than 10 years of operation. For types of business, it was also dummy coded as follows, " 1 " - Production of agricultural products, "0" - Services, "0" - Manufacturing. For business registration status, the control variable was coded as; "1" - Private limited company, "0" - Sole Proprietorship, "0" - Partnership.

The dependent variables computed based on average sales, assets and capital between the years $2000-2003$. Data on net profits were collected during the same period and was averaged and computed as follows:

a) Return on Sales $(\mathrm{ROS})=$ Average Net Profit/Average Sales

b) Return on Assets $(\mathrm{ROA})=$ Average Net Profit/Average Assets

c) Return on Invested Capital (ROIC) = Average Net Profit/Average Capital

All loaded dimensions in DC and EO tested for construct validity and internal consistency using reliability. Each dimension loaded under DC and EO were summated using mean average as suggested by Hair, et al. (1998). All the variables analyzed using frequency to describe the data.

Step 2 observed the acceptance or rejection of the research hypotheses. A Pearson correlation analysis and four-step regression analysis were used as basis for the final decisions. The first step analyzed interactions of control variables on the relationships between the independent variable and the dependent variable. The second step determined direct relationships between the independent variable and mediator variables. The third step ascertained independent and mediator variables relationship to dependent variable. The fourth step observed changes in beta of independent variable when mediator variable was included into the analysis (Baron \& Kenny, 1986). The path significance was ascertained utilizing $t$-test formula as follows: $t=\beta_{\mathrm{a}} \beta_{\mathrm{b}} / \mathrm{s}_{\beta \mathrm{a}} \mathrm{b}$, computed $t$ value compared to $t$ value in the table (Baron \& Kenny, 1986). The analysis produced regression models from which the researchers decided by referring to the coefficient of determination in $R^{2}$ determined by significance level of .01 or .05 of $F$-value. Power was determined to ensure level of probability in finding significant correlation using specified parameter in the study. Power equivalent to the effect size of $\mathrm{f}^{2}=R^{2} /\left(1-R^{2}\right)=.53$ with sample size 100, the power was .94 at $p<.05$ and .83 at $p<.01$ (Cohen et al., 2003) (Refer exhibit 1).

\subsection{Factor Analysis}

The analysis for EO was computed in five stages; where the first stage and the second stage observed two items being deleted from the analysis due to low anti-image measures of sampling adequacy (MSA) i.e. less than .50, from the third, fourth, and fifth stage observed another nine items were being deleted due to cross-loadings. The final analysis was computed with only eighteen items that produced Kaiser-Meyer-Olkin (KMO) measure of sampling adequacy of 0.80 with Bartlett sphericity test produced chi-square $=1064.01$ at degree of freedom $=$ 153 , significant at .00. Four components produced where each component explained more than 1.0 eigenvalue and the variance explained 64.23 percent. The component significantly loaded on four dimensions where each item carried more than 0.40 loadings as proposed by Hair et al. (1998) necessary for total sample size of 120 .

The labeling of the components maintained the original label used by Lumpkin and Dess (1996). Even though some of the components contained mixed items, most of the items corresponded to the original component. Component 1 loaded with seven items; four items under competitive aggressiveness, two items under 
innovativeness, and one item under autonomy - labeled as Competitive Aggressiveness. Component 2 loaded with five items; three items under proactiveness and two other items were each identified under risk-taking and autonomy - labeled as proactiveness. Component 3 loaded with four items; 2 items under risk-taking and another 1 item each under proactiveness and innovativeness - labeled as risk-taking. Component 4 loaded with two items; one under innovativeness and one under risk-taking - labeled as innovativeness (Refer table 1).

Four dimensions of EO showed the distinctiveness between dimensions when each of them sufficiently explained by the variance. The finding lent support to H1 where each EO dimensions were independent from each other.

The analysis for distinctive capabilities computed in four stages; where during the first stage all items identified exceeded MSA anti-image of .50 but 13 items deleted due to cross-loadings. The second stage further deleted six items due to similar result. During the third stage of computation, another six items deleted due to cross-loadings. During the forth stage of computation the analysis produced Kaiser-Meyer-Olkin (KMO) measure of sampling adequacy of 0.77 with Bartlett sphericity test produced chi-square $=1724.83$ at degree of freedom $=378$, significant at $p<.01$. Eight components identified and each component explained by more than 1.0 eigenvalue and the variance explained by 70.81 percent.

The labeling for distinctive capabilities was inevitable when additional items mixed with the original items used by Hitt and Ireland (1985). Hitt and Ireland (1985) used seven components in their variables but this research used eight components. Component 1 loaded with four items; two items under operation and production, one item each under marketing and general administration - labeled as Development process. Component 2 loaded with five items; four items under finance and one item under personnel - labeled as Financial Information. Component 3 loaded with four items; three items under personnel and one item under production and operation labeled as Human Resource Management. Component 4 loaded with three items under financial - labeled as Capital Structure. Component 5 loaded with one item under marketing and two items under general administration - labeled as General Administration. Component 6 loaded with two items under general administration and one item under production and operation - labeled as Entrepreneurial Management. Component 7 loaded with two items under production and operation and one item under marketing - labeled as Information Technology. Component 8 loaded with one item each under engineering and production and operation - labeled as Engineering. (Refer table 2)

Findings in factor analysis for DC proved independence of each dimension. Each dimension accounted sufficient eigenvalue of more than one and 3 percent of variance for each dimension, which explained the dimensions vary from each other. Therefore, $\mathrm{H} 2$ supported.

\subsection{Descriptive Analysis}

Most of the respondents represented mainly by male constituted $76.8 \%$ of all respondents. Respondents' level of education primarily represented by $76.8 \%$ primary school level and the rest of $23.2 \%$ were secondary school leavers. Age bracket of respondents were older where $76.6 \%$ whose age were more than 40 . Most of the respondents were the owner of the firm i.e. $97.6 \%$ of the respondents.

Firms' demographic type of business venture, $64.8 \%$ was manufacturers of agricultural products, $24.8 \%$ were producers of agriculture products and $10.4 \%$ were services. Large portion of the responded firms were sole proprietors i.e. $91.2 \%, 5.6 \%$ private limited companies and 3.2\% partnership. Most of the firms operated less than 10 years, i.e. $76.8 \%$, and $23.2 \%$ operated more than 10 years.

Firms financial performance structure of respondents were those of small-sized firms where the average sales, assets and capital were less than RM50, 000 represented by $92 \%, 97.6 \%$ and $98.4 \%$ respectively. Only 8\%, 2.4\% and $1.6 \%$ were those with more than RM50, 000 sales, assets and capital respectively.

Range, skewness, measures of central tendency, reliability and inter-correlation produced after a mean summated scale done to each dimension. Lowest range was between 1.00 and 2.75 and the highest was between 5.40 and 7.00. Skewness showed value between the lowest $(-1.24)$ to the highest $(0.23)$. Highest mean among DC dimensions was general administration capability with 5.86 and the lowest was financial information capability with 4.57. For EO the mean ranges between 3.87 and 4.73. Standard deviation (SD) showed a disperse distribution for all EO dimensions and five DC dimensions with value more than 1.00, however, three DC dimensions showed SD less than one (Refer table 3).

Reliability showed all DC dimensions the Cronbach's alpha more than .60 and three EO dimensions showed reliability more than .70 and 1 dimension (innovativeness) with .54 . All dimensions were acceptable according 
to Nunnally (1978) and Hair et al. (1998) except innovativeness; however researcher decided to maintain the dimension.

\subsection{Correlation Analysis}

Correlation analysis showed significant relationship between EO and DC provided support to H3. Development process capability correlated positively to all dimensions of EO at $p<.01$, however, financial information capability showed a significant correlation to competitive aggressiveness but in negative direction. Human resource and capital structure capabilities correlated significantly to risk taking and innovativeness at $p<.01$. General administration capability correlated to competitive aggressiveness and risk taking at $p<.01$ and proactiveness at $p<.05$. Entrepreneurial management capability correlated to competitive aggressiveness and proactiveness at $p<.01$. Information technology capability did not correlate to any EO dimensions. Engineering capability correlated to proactiveness at $p<.01$ (Refer table 3 ).

\subsection{Multiple Regression Analysis}

\subsubsection{EO - DC Relation}

The MRA treated each DC dimensions separately as dependent variables regressed on all four EO dimensions. In explaining the interaction of control variables, MRA produced eight models. However, findings ascertained five models i.e. Process development $\left(R^{2}=.28, F=15.68, p<.01\right)$, financial information $\left(R^{2}=.34, F=20.25, p\right.$ $<.01)$, human resources $\left(R^{2}=.15, F=7.05, p<.01\right)$, general administration $\left(R^{2}=.19, F=9.43, p<.01\right)$, and entrepreneurship management $\left(R^{2}=.21, F=10.61, p<.01\right)$. The models sufficiently explained the variance or coefficient of determination or the $R^{2}$ in the effect of control variables on EO-DC relations. Private limited company explained EO and process development capability (Beta $=.16, p<.05)$. All three controls affected on financial information EO relation when firms' age was more than 10 years (Beta $=.26, p<.01)$, firms that produce agriculture product $($ Beta $=.69, p<.01)$ and private limited company $($ Beta $=.19, p<.05)$. Moreover, EO human resource capability relation found affected by private limited company firms $($ Beta $=.28, p<.01)$. Even though the model for EO general administration relation was significant, effect of control variables were in negative directions. Private limited company played significant role in affecting EO entrepreneurship management relations $($ Beta $=.17, p<.05)$.

In explaining the effect of EO dimensions on each DC dimensions, all eight models showed sufficient explanation in the variance. EO and process development capability relations explained $59 \%$ of the variance when proactiveness $($ Beta $=.24, \mathrm{p}<.01)$, risk taking $($ Beta $=.43, p<.01)$ and innovativeness $($ Beta $=.22, p<.01)$ showed strong relationship. Even though model of financial information capability showed $51 \%$ variation in EO explaining the relationship, only innovativeness showed positive relation (Beta $=.24, p<.01$ ). Human resource capability model explained $46 \%$ of the variance when risk taking (Beta $=.45, p<.01)$ and innovativeness (Beta $=.26, p<.01)$ proved significant positive relation. In the same vein, $\mathrm{EO}$ and capital structure capability relations showed $35 \%$ of the variance explaining significance of risk taking (Beta $=.21, p<.05)$ and innovativeness (Beta $=.42, p<.01)$. In EO general administration capability relation, $30 \%$ the variance explained significance of competitive aggressiveness $($ Beta $=.40, p<.01)$. EO entrepreneurship management capability relation showed $37 \%$ of the variance when both competitive aggressiveness and risk taking (Beta $=.34, p<.01$ ) significantly explained. The model of EO information technology capability relatedness showed $14 \%$ explanation in the variance when competitive aggressiveness (Beta $=.32, p<.01)$ and innovativeness $($ Beta $=.20, p<.05)$ significantly related. Finally, EO engineering capability relation proved $26 \%$ of the variation for proactiveness $($ Beta $=.46, p<.01)$ significant relation (Refer table 4$)$.

EO and DC strongly related whereby at least one item in EO found significantly related to each DC, therefore, H3 supported.

\subsubsection{DC-ROS Relation}

MRA produced ROS as performance variable that has significant explanation of EO and DC relations, whereas ROA and ROIC showed insignificant variation in the independent and mediator variables. Therefore, only ROS fit for use as dependent variable in the following MRA.

The effect of control variables on the relationship between DC and the ROS showed significant model when the coefficient of determination explained $24 \%$ of the variance in firms that operated more than 10 years $(\mathrm{Beta}=.34$, $p<.01)$ and production firms $($ Beta $=.48, p<.01)$.

The direct relationship between DC and ROS proved significant when the coefficient of determination explained $48 \%$ of the variance. Financial information capability found as the only DC dimension explained ROS (Beta $=.55, p<.01)($ Refer table 5$)$. Therefore, $H 4$ partially supported. 


\subsubsection{EO - ROS Relationship Mediated by DC}

Testing EO - ROS relationship with DC as the mediator was done in three stages. First stage observed significant effect of control variables in EO-ROS relationship showed by $24 \%$ of the variance explained. Older firm (more than 10 years) (Beta $=.34, p<.01)$ and production firm (Beta $=.48, p<.01)$ showed significant effect on the relationship.

Second stage proved significant explanation of EO in relation to ROS by $51 \%$ of the variation in each dimensions when competitive aggressiveness (Beta $=. .53, p<.01)$ and innovativeness (Beta $=.21, p<.01$ ) predicted ROS.

Third stage witnessed the mediated effect of financial information capability of DC between innovativeness of EO and ROS relationship. The model significantly explained by $55 \%$ of the variance of the coefficient of determination reduced the effect of innovativeness (Beta $=.14, p<.05)$ when financial information capability included into the analysis (Beta $=.28, p<.01)$ (Refer Table 6). Furthermore, post-hoc analysis to confirm mediated effect utilized a $t$-test of $t=\beta_{\mathrm{a}} \beta_{\mathrm{b}} / \mathrm{s}_{\beta a \beta b}$ produced $t=2.88$ at degree of freedom (df) $4-1=3$, which was significant compared to $t$-value in the table (1.89).

Based on the finding, the researchers concluded that there was mediating effect of financial information on innovativeness - ROS relation. Therefore, H5 and H6 partially supported.

\section{Discussions}

This research explored dimensions within EO and DC and their relationship, besides their impact on financial performance. Factor analysis produced four dimensions of EO with 18 items and eight dimensions of DC with 28 items sufficiently explained by the variance. Each EO dimensions was the mixture of few items belonging to other dimensions, however the label remained. On the other hand, DC's dimensions witnessed some changes in six labels whereas only two labels' remained.

Some control variables proved significant in explaining some relationships. Older firms, producers and private limited companies affected EO-financial information relationship. Older firms and producers affected DC-ROS as well as EO-DC-ROS relationship. Older firms and producers seem pertinent in all relationship studied. The phenomenon warrants further investigation in the analysis of this study or they worth consideration in future studies. Private limited companies are more sensitive to financial reporting compared to other form of business. Older firms constitute longer tenure in business involvement among firms that perform beyond ROS; they are in growth or maturity stage of the firms' life cycle. Similarly, producers affect the relationship due to their cycle of price, product and production.

Alvarez and Barney (2000) argued that entrepreneurial firms possessed heterogeneous resources, which supported the factors in this research. Heterogeneity of the firms' resources embedded in both EO and DC, signify entrepreneurial firms maintained its characteristics as rare, valuable, inimitable, and non-substitutable (Barney, 1995). Similarly, Kilby (1971) reiterated that entrepreneurs are existed entity but beyond explanation. Arguably, heterogeneity of the firm existed due to observed property rights taking the form of patents, trademarks, and copyrights. Trade secrets, proprietary information or technology further isolate the firm from its competitors, however, the mechanisms will deteriorate, entrepreneurs must prepare for quick decision to establish better competitive positions (Dollinger, 1994). DC factors supported resource types categorized by Dollinger (1994). They are such as, financial, physical, human, technological, reputational, and organizational resources.

The findings proved that EO and DC are strongly related. According to Covin and Slevin (1991) EO is a stand-alone variable that explain types of resources found in DC. Similarly, Khandwalla (1977) postulated that strategic variables include both entrepreneurial strategies and resources strategies, and his findings singled-out entrepreneurial strategies.

Both EO and DC explained performance significantly. However, two EO dimensions explain performance in different direction. Innovativeness proved positive relationship to performance, whereas competitive aggressiveness explained performance negatively. The finding supports Kreiser et al. (2002), and Lumpkin and Dess (2001) who establish similar pattern of relationship.

Furthermore, the finding partially supports Hitt and Ireland (1985) who found all DC dimensions related to performance positively. This research identified financial information positively related to ROS, but entrepreneurial management and ROS related negatively. The finding explained that performance of agro-based firms does not depend so much on entrepreneurial management. 
Our findings proved that financial information mediated innovativeness-ROS relationship. The mediation proved innovativeness directly related to ROS established in the second step of analysis; however the relationships became weaker showed in lower standardized beta when financial information (mediator) is added to the analysis in the third step of analysis (Baron \& Kenny, 1986). Covin and Slevin (1991) postulated that organizational resources and competencies should play either a moderating or mediating roles on EO Performance relation. The finding ascertained claim by Lumpkin and Dess (1996), Lieberman and Montgomery (1988) who conceptualized that strategic resources variables such as competencies, organizational culture, first-mover advantage and quick-response mediated EO - Performance relation.

\section{Implications and Future Research}

Theoretical implication derived from the findings and discussions shows contribution to the resource-based view (RBV) when the multidimensionality of distinctive capabilities within agro-based firms ascertained. Physical and managerial resources as domain for improvement seem promising when the dimensions significantly explained agro-based firms in Malaysia. Similarly, the finding emphasized that EO is part of the entrepreneurial capabilities identified (Alvarez \& Barney, 2000). Contribution to performance relationship, both EO and DC played critical role as the determinants. Moreover, the study proved financial information facilitates innovativeness in achieving higher performance.

From the managerial perspectives, the findings will help managers to decide on more innovative approaches in using financial information to enhance firm's sales performance. Managers of agro-based firms should emphasize in these competencies in their respective agro business ventures. All the competencies of EO and DC are independent to each other require separate treatment. Establishing systematic approach of instilling these competencies to the firms should be on incremental basis.

Future studies should embark into additional independent/mediator/moderator variables such as, level of knowledge, quick response and strategic leadership among agro-based entrepreneurs and how it relates to strategy, technology and strategic alliances. In term of dependent variables, entrepreneurial rent, entrepreneurial outcomes, number of innovations worth considered. Antecedents and determinants of agro-based firms' competitive advantage demand in-depth study for the development of the sector to compete in new landscapes. Sample frame should be extent to cover the whole of Malaysia and neighboring countries such as Thailand and Indonesia.

\section{Conclusion}

The study explores entrepreneurial orientation and distinctive capabilities dimension as determinant of financial performance among agro-based firms in the state of Kedah. Sample frame comprises of 600 agro-based firms throughout the state of Kedah. Only 125 firms responded to the study, which made up 35\% response rate. The analysis executed in two stages, the first stage was factor analysis that verify the validity of the construct, the second stage observed the descriptive, correlation and multiple-regression analysis. The findings produced four factors for EO and eight factors for DC. Dependent variables computed from averages in sales, assets and capital producing indicators of ROS, ROA, and ROIC. EO and DC found to be highly correlated and one dimension under each of them found significantly explained ROS. The financial information under DC is found to mediate the EO - ROS relationship. The study supported the resource-based view (RBV) whereby EO and DC were strategic internal resources of the firm pertinent in enhancing performance. Finally, we suggest future studies in advancing entrepreneurship theory.

\section{References}

Alvarez, S. \& Barney, J. (2000). Entrepreneurial capabilities. In G. D. Meyer \& K. A. Heppard (Eds.), Entrepreneurship As Strategy: Competing on the Entrepreneurial Edge (pp. 63-81). Thousand Oaks, CA: Sage Publications Inc.

Andrew, K. R. (1980). The Concept of Corporate Strategy (Rev. ed.). Homewood, IL: Richard D. Irwin.

Awang, A. (2006). Firm's Entrepreneurial Orientation and Bumiputera SMEs Performance: The Impact of Some Perceived Environmental Factors. Unpublished PhD Thesis, University Science Malaysia, Penang.

Awang, A. \& Ahmad, Z. A. (2005). Firm's entrepreneurial orientation and bumiputera SMEs performance: The impact of munificent environment. $7^{\text {th }}$ International Research Conference on Quality, Innovation and Knowledge Management, Monash University.

Barney, J. B. (1991). Firm resources and sustained competitive advantage. Journal of Management, 17, 99-120.

Barney, J. B. (1995). Looking inside for competitive advantage. In Mariana Mazzucato (Eds.), Strategy for 
Business (pp. 161-176). London: Sage Publications.

Baron, R. M. \& Kenny, D. A. (1986). The moderator-mediator variable distinction in social psychology research: Conceptual, strategic, and statistical considerations. Journal of Personality and Social Psychology, 51, 1173-1182.

Bettis, R. A. \& Hitt, M. A. (1995). The new competitive landscape. Strategic Management Journal, 16, 5-14.

Brown, T. E. (1996). Resource orientation, entrepreneurial orientation and growth: How the perception of resources availability affects small firm growth. Newark, NJ: Rutgers University.

Bygrave, W. D. (1989). The entrepreneurship paradigm (I): A philosophical look at its research methodologies. Entrepreneurship Theory and Practice, 14(1), 7-26.

Cohen, J., Cohen, P., West, S. G. \& Aiken, L. S. (2003). Applied multiple regression/correlation analysis for the behavioral sciences ( $3^{\text {rd }}$ ed.)., Erlbaum, Hillsdale, NJ.

Covin, J. G. \& Covin, T. J. (1990). Competitive aggressiveness, environmental context, and small firm performance. Entrepreneurship Theory \& Practice, 14, 35-50.

Covin, J. G. \& Slevin, D. P. (1991). A conceptual model of entrepreneurship as firm behavior, Entrepreneurship Theory \& Practice, 16, 7-25.

Dean, C. C. (1993). Corporate entrepreneurship: Strategic and structural correlates and impact on the global presence of United States firms. Unpublished doctoral dissertation, University of North Texas, Denton.

Dess, G. G., Lumpkin, G. T. \& Covin, J. G. (1997). Entrepreneurial strategy making and firm performance: Tests of contingency and configurational models. Strategic Management Journal, 18(9), 677-695.

Dollinger, M. J. (1994). Entrepreneurship: Strategies and Resources. Richard D. Irwin: Burr Ridge, IL.

Gartner, W. (1985). A conceptual framework for describing the phenomenon of new venture creation. Academy of Management Review, 10(4), 696-706.

Hall, R. (1993). A framework linking intangible resources and capabilities to sustainable competitive advantage. Strategic Management Journal, 14, 607-618.

Hair, J. F., Anderson, R. E., Tatham, R. L. \& Black, W. C. (1998). Multivariate Data Analysis (5 ${ }^{\text {th }}$ ed.), Prentice-Hall International, Inc., Upper Saddle River, NJ.

Hashim, M. K. (2000). A proposed strategic framework for SMEs success. Malaysian Management Review, 35( 2), 32-43.

Hashim, M. K., Mohammad, O. \& Wafa, S. A. (2001). Domestic versus export-oriented SMEs: Evaluating their perceived distinctive capabilities. Malaysian Management Review, 36(2), 45-53.

Hayes, R. H., Wheelwright, S. C. \& Clark, K. B. (1988). Dynamic Manufacturing: Creating the Learning Organization. New York: Free Press.

Hitt, M. A. \& Ireland, R. D. (1985). Corporate distinctive competence, strategy, industry and performance. Strategic Management Journal, 6, 273-293.

Hitt, M. A., Ireland, R. D. \& Hoskisson, R. E. (2003). Strategic management: Competitiveness and globalization, South-Western College Publishing, Mason, OH.

Hofer, C. W. \& Schendel, D. (1978). Strategy Formulation: Analytical Concepts. St Paul, MN: West Publishing.

Itami, H. \& Roehl, T. (1987). Mobilizing Invisible Assets. Cambridge, MA: Harvard University Press.

Khandwalla, P. N. (1977). The Design of organizations. Harcourt Brace Jovanovich, New York.

Kilby, P. (1971). Entrepreneurship and Economic Development. New York: Free Press.

Kreiser, P., Marino, L. \& Weaver, K. M. (2002). Assessing the relationship between entrepreneurial orientation, the external environment, and firm performance, Frontiers of Entrepreneurship Research [Online], Available: http://www.babson.edu/entrep/fer/Babson2002/X/X_P3/P3.htm (March 25, 2003).

Kuratko, D. F. \& Welsch, H. P. (2001). Strategic Entrepreneurial Growth. Fort Worth, TX: Harcourt College Publishers.

Lieberman, M. \& Montgomery, D. (1988). First-mover advantages. Strategic Management Journal, (Special Issue), 9, 41-58. 
Low, M. \& McMillan, A. C. (1988). Entrepreneurship: Past research and future challenges. Journal of Management, 14, 139-141.

Lumpkin, G. T. \& Dess, G. G. (1996). Clarifying the entrepreneurial construct and linking it to performance. Academy of Management Review, 21(1), 135-172.

Lumpkin, G. T. \& Dess, G. G. (2001). Linking two dimensions of entrepreneurial orientation to firm performance. Journal of Business Venturing, 16(5), 429-451.

Lyon, D. W., Lumpkin, G. T. \& Dess, G. G. (2000). Enhancing entrepreneurial orientation research: Operationalizing and measuring a key strategic decision making process. Journal of Management, 26(5), 1055-1085.

Malaysia. (2003). Economic Report 2002/2003. Kuala Lumpur: Malaysian National Printers Limited.

Malaysia. (2006). Ninth Malaysia Plan (2006-2010). Kuala Lumpur: Malaysian National Printers Bhd.

Miller, D. (1983). The correlates of entrepreneurship in three types of firms. Management Science, 29, $770-791$.

Miller, D. (1987). The structural and environmental correlates of business strategy. Strategic Management Journal, 8(1), 55-76.

Miller, D. (1988). Strategic process and content as mediators between organizational context and structure. Academy of Management Journal, 31(3), 544-569.

Miller, D. \& Friesen, P. (1982). Innovation in conservative and entrepreneurial firms. Strategic Management Journal, 3(1), 1-27.

Nunnally, J. C. (1978). Psychometric Theory. New York: McGraw-Hill.

Ones, D., Reiss, A. D. \& Viswevaran, C. (1996). Role of social desirability in personality testing for personnel selection: The red herring. Journal of Applied Psychology, 81(6), 660-679.

Pavitt, K. (1991). Key characteristics of the large innovating firm. British Journal of Management, 2, 41-50.

Podsakoff, P. M. \& Organ, D. W. (1986). Self-reports in organizational research: Problems and prospects. Journal of Management, 12(4), 531-543.

Prahalad, C. K. \& Hamel, G. (1990). The core competence of the corporation. Harvard Business Review, (May-June), 79-91.

Rumelt, R. (1994). Foreword. In G. Hamel \& A. Heene (eds), Competence-Based Competition. New York: Wiley, xv-xix.

Selznick, P. (1947). Leadership in Administration: A Sociological Perspective. New York: Harper.

Shane, S., Venkatraman, S. \& McMillan, I. (1995). Cultural differences in innovation championing strategies. Journal of Management, 21, 931-952.

Smart, D. T. \& Conant, J. S. (1994). Entrepreneurial orientation, distinctive marketing competencies and organizational performance. Journal of Applied Business Research, 10(3), 28-38.

Snow, C. C. \& Hrebiniak, L. G. (1980). Strategy, distinctive competence, and organizational performance. Administrative Science Quarterly, 25, 317-335.

Stevenson, H., Roberts, M. \& Grousbeck, H. (1989). New Business Ventures and the Entrepreneur. Richard D. Irwin: Burr Ridge, IL.

Teece, D. J., Pisano, G. \& Shuen, A. (1999). Dynamic capabilities and strategic management. In Knowledge and Strategy (pp. 77-116), M. H. Zack (ed), Butterworth-Heinermann, Boston.

Wernerfelt, B. (1984). A resource-based view of the firm. Strategic Management Journal, 5, 171-180.

Wilklund, J. (1998). Entrepreneurial Orientation as predictor of performance and entrepreneurial behavior in small firms - Longitudinal evidence. Frontier of Entrepreneurship Research. [Online] Available: http://www.babson. edu/entrep/fer/papers98/IX/IX_E/IX_E_text.htm (March 12, 1999).

Wilklund, J. (1999). The sustainability of the entrepreneurial orientation-performance relationship, Frontiers of Entrepreneurship Research, Available:http://www.babson.edu/entrep/fer/papers98/IX/IX_E/IX_E_text.htm (March 12, 1999].

[Online]

Wilklund, J. \& Shepherd, D. (2003). Knowledge-based resources, entrepreneurial orientation, and the performance of small and medium-sized businesses. Strategic Management Journal, 24, 1307-1314. 
Zahra, S. A. (1991). Predictors and financial outcomes of corporate entrepreneurship: An exploratory study. Journal of Business Venturing, 6, 259-285.

Table 1. Factor Analysis on Entrepreneurial Orientation

\begin{tabular}{|c|c|c|c|c|}
\hline \multirow[b]{2}{*}{ Item-item } & \multicolumn{4}{|c|}{ Loaded Factors } \\
\hline & 1 & 2 & 3 & 4 \\
\hline \multicolumn{5}{|l|}{ 1. Aggressive competitiveness } \\
\hline a. Market leader & .88 & .13 & -.13 & -.05 \\
\hline b. Workers involvement irregardless of rank & .87 & -.02 & .15 & -.09 \\
\hline c. Strategy to overcome competition & .84 & -.16 & .02 & -.12 \\
\hline d. Actively responding to market changes & .76 & .21 & .30 & .22 \\
\hline e. Product modification & .71 & .39 & -.05 & .01 \\
\hline f. New method & .71 & -.39 & .23 & .10 \\
\hline g. Competing using outstanding strategies & .60 & -.06 & -.10 & -.34 \\
\hline \multicolumn{5}{|l|}{ 2. Proactiveness } \\
\hline a. Investing in high cost project & .10 & .79 & .00 & -.14 \\
\hline b. Workers are free to make decision & -.18 & .70 & .10 & .07 \\
\hline c. Taking opportunity outside one's field & -.13 & .65 & .21 & .21 \\
\hline $\begin{array}{l}\text { d. Workers introducing new approaches even } \\
\text { if they have to overrule certain work procedures. }\end{array}$ & .06 & .62 & -.39 & .27 \\
\hline e. Taking action to be better than competitors & .33 & .61 & .06 & -.04 \\
\hline \multicolumn{5}{|l|}{ 3. Risk taking } \\
\hline a. Taking stern action to achieve mission & .09 & .19 & .71 & .43 \\
\hline b. Practice prompt actions & .14 & .05 & .70 & .14 \\
\hline c. Having confident to achieve company's mission & .43 & .13 & .70 & .18 \\
\hline d. Renewal is of utmost importance & -.33 & -.11 & .67 & -.14 \\
\hline \multicolumn{5}{|l|}{ 4. Innovativeness } \\
\hline a. Continuous investment in new technology & -.03 & -.07 & .10 & .81 \\
\hline b. Large investment in producing new product & -.11 & .14 & .13 & .72 \\
\hline Eigenvalue & 4.83 & 3.06 & 2.46 & 1.21 \\
\hline Percentage of Variance & 26.81 & 17.02 & 13.69 & 6.72 \\
\hline Cumulative $\%$ of Variance & 26.81 & 43.83 & 57.51 & 64.23 \\
\hline
\end{tabular}


Table 2. Factor Analysis on Distinctive Capabilities

\begin{tabular}{|c|c|c|c|c|c|c|c|c|}
\hline \multirow[b]{2}{*}{ Item-item } & \multicolumn{8}{|c|}{ Loaded Factors } \\
\hline & 1 & 2 & 3 & 4 & 5 & 6 & 7 & 8 \\
\hline \multicolumn{9}{|l|}{ 1. Development Process } \\
\hline a. Determining capacity/contract & .82 & .13 & -.00 & .02 & .14 & -.10 & .16 & .05 \\
\hline b. Layout and environment & .79 & -.16 & .13 & -.01 & .04 & .17 & -.03 & .15 \\
\hline c. Marketing research & .76 & -.15 & .33 & .15 & .02 & -.04 & .03 & -.00 \\
\hline d. Strategic planning & .64 & -.18 & .39 & .28 & .09 & .06 & .05 & .15 \\
\hline e. Research \& Development & .62 & -.21 & .14 & .19 & .06 & .28 & .09 & .04 \\
\hline \multicolumn{9}{|l|}{ 2. Financial Information } \\
\hline a. Risk management & -.33 & .79 & -.06 & .15 & -.08 & -.05 & .15 & .22 \\
\hline b. Shares status & -.26 & .78 & .08 & .32 & -.05 & .01 & .09 & .11 \\
\hline c. Return to shareholders & -.03 & .75 & .02 & .40 & -.05 & -.04 & .12 & -.03 \\
\hline d. Relationship with associations & .03 & .66 & .09 & -.20 & .19 & .02 & .06 & -.14 \\
\hline c. Tax management & .10 & .51 & .07 & .33 & .33 & .22 & -.01 & -.19 \\
\hline \multicolumn{9}{|l|}{ 3. Human Resources } \\
\hline a. Workers performance & .19 & .17 & .81 & .14 & .13 & .18 & .03 & -.14 \\
\hline b. Motivation and job satisfaction & .10 & .31 & .74 & -.07 & -.11 & -.08 & .05 & .22 \\
\hline c. Production/service capacity & .42 & -.18 & .65 & .12 & .25 & .12 & .06 & .08 \\
\hline d. Recognition \& compensation & .21 & -.13 & .60 & .25 & .06 & .20 & .03 & -.25 \\
\hline \multicolumn{9}{|l|}{ 4. Capital Structure } \\
\hline a. Financial relationship & .33 & .26 & .26 & .72 & -.06 & .03 & -.04 & -.04 \\
\hline b. Capital structure & -.02 & .30 & -.03 & .71 & .31 & .12 & .10 & -.03 \\
\hline c. Working capital & .27 & .04 & .26 & .54 & -.15 & .15 & .24 & .07 \\
\hline \multicolumn{9}{|l|}{ 5. General Administration } \\
\hline a. Pricing strategy & .07 & .15 & .00 & .03 & .79 & .05 & .04 & .07 \\
\hline b. Enforcement of mission & -.01 & -.07 & .39 & .12 & .74 & .15 & .07 & .05 \\
\hline c. Unity of opinion & .34 & -.04 & -.11 & -.10 & .66 & -.01 & .23 & .25 \\
\hline \multicolumn{9}{|l|}{ 6. Entrepreneurial mgt. } \\
\hline a. Maintaining trained managers & -.07 & .05 & .00 & .03 & .19 & .86 & .00 & .03 \\
\hline b. Modernization of plant/equip. & .15 & -.24 & .26 & .19 & -.16 & .65 & .23 & .02 \\
\hline c. Look for new opportunity & .43 & .28 & .19 & .09 & .13 & .63 & -.06 & -.02 \\
\hline \multicolumn{9}{|l|}{ 7. Information Technology } \\
\hline a. Cost of computer system & -.10 & .09 & .06 & .03 & .11 & -.10 & .87 & .09 \\
\hline b. Computer system and power & .17 & .24 & .05 & .42 & .06 & .09 & .67 & .19 \\
\hline c. Bigger contract work & .31 & .09 & .04 & -.02 & .12 & .25 & .63 & -.15 \\
\hline \multicolumn{9}{|l|}{ 8. Engineering } \\
\hline a. Expenses on R \& D & .06 & .09 & .15 & -.07 & .13 & .04 & -.04 & .86 \\
\hline b. Automation in manufacturing & .24 & -.11 & -.22 & .09 & .13 & -.00 & .17 & .74 \\
\hline Eigenvalue & 6.42 & 4.07 & 2.34 & 1.82 & 1.56 & 1.32 & 1.29 & 1.01 \\
\hline Percentage of Variation & 22.93 & 14.52 & 8.35 & 6.49 & 5.58 & 4.70 & 4.60 & 3.63 \\
\hline$\%$ of Cummulative Variation & 22.93 & 37.46 & 45.81 & 52.30 & 57.88 & 62.58 & 67.18 & 70.81 \\
\hline
\end{tabular}


Table 3. Descriptives and Intercorrelations among Variables in the Study

\begin{tabular}{|c|c|c|c|c|c|c|c|c|c|c|c|c|c|c|c|c|c|c|}
\hline Variables & Mean & SD & 1 & 2 & 3 & 4 & 5 & 6 & 7 & 8 & 9 & 10 & 11 & 12 & 13 & 14 & 15 & 16 \\
\hline $\begin{array}{l}\text { Control } \\
\text { 1. Firm age }(>10)^{\mathrm{a}} \\
\text { 2. Producers } \\
\text { 3. Private Ltd Co. }\end{array}$ & $\begin{array}{l}\text { (nc) } \\
\text { (nc) } \\
\text { (nc) }\end{array}$ & $\begin{array}{l}\text { (nc) } \\
\text { (nc) } \\
\text { (nc) }\end{array}$ & $\begin{array}{l}(\mathrm{nc}) \\
-.47^{* *} \\
.12\end{array}$ & $\begin{array}{l}(\mathrm{nc}) \\
-.34 * *\end{array}$ & (nc) & & & & & & & & & & & & & \\
\hline $\begin{array}{l}\text { Dependent } \\
\text { 4. ROS }\end{array}$ & (nc) & (nc) & .11 & $.36^{* *}$ & $-.25 * *$ & (nc) & & & & & & & & & & & & \\
\hline $\begin{array}{l}\text { Mediator } \\
\text { 5. Production/Oper } \\
\text { 6. Financial info. } \\
\text { 7. Personnel } \\
\text { 8. Capital structure } \\
\text { 9. General admin. } \\
\text { 10. Entrepren. Mgt } \\
\text { 11. Info. Tech. } \\
\text { 12. Engineering }\end{array}$ & $\begin{array}{l}4.79 \\
4.57 \\
5.14 \\
4.86 \\
5.86 \\
5.58 \\
4.78 \\
4.64\end{array}$ & $\begin{array}{r}1.11 \\
1.16 \\
.85 \\
1.10 \\
.82 \\
.86 \\
1.04 \\
1.30\end{array}$ & $\begin{array}{l}.14 \\
-.07 \\
.01 \\
.02 \\
-.04 \\
.03 \\
-.11 \\
.07\end{array}$ & $\begin{array}{l}-.52^{* *} \\
.51^{* *} \\
-.26^{* *} \\
.01 \\
-.19^{*} \\
-.24^{* *} \\
.00 \\
-.14\end{array}$ & $\begin{array}{l}.34^{* *} \\
-.01 \\
.34^{* *} \\
.21^{*} \\
.25^{* *} \\
.24^{* *} \\
.15 \\
.11\end{array}$ & $\begin{array}{l}-.18^{*} \\
.54^{* *} \\
-.03 \\
.19^{*} \\
-.20^{*} \\
.14 \\
-.07 \\
.03\end{array}$ & $\begin{array}{l}(.83) \\
-.15 \\
.51^{* *} \\
.36^{* *} \\
.32^{* *} \\
.30^{* *} \\
.26^{* *} \\
.24^{* *}\end{array}$ & $\begin{array}{l}(.82) \\
.11 \\
.43 * * \\
.01 \\
.08 \\
.29 * * \\
.00\end{array}$ & $\begin{array}{l}(.78) \\
.40^{* *} \\
.28^{* *} \\
.38^{* *} \\
.21^{*} \\
.03\end{array}$ & $\begin{array}{l}(.69) \\
.16 \\
.34^{* *} \\
.35^{* *} \\
.05\end{array}$ & $\begin{array}{l}(.60) \\
.23 * * \\
.30^{* *} \\
.30^{* *}\end{array}$ & $\begin{array}{l}(.67) \\
.24 * * \\
.05\end{array}$ & $\begin{array}{l}(.69) \\
.17\end{array}$ & $(.64)$ & & & & \\
\hline $\begin{array}{l}\text { Independent } \\
\text { 13. Aggressiveness } \\
\text { 14. Proactiveness } \\
\text { 15. Risk taking } \\
\text { 16. Innovativeness }\end{array}$ & $\begin{array}{l}3.94 \\
3.87 \\
4.73 \\
4.30\end{array}$ & $\begin{array}{l}1.29 \\
1.02 \\
1.01 \\
1.11\end{array}$ & $\begin{array}{r}.06 \\
.03 \\
.00 \\
. .01\end{array}$ & $\begin{array}{l}-.53^{* *} \\
-.15 \\
-.36 \\
-.11\end{array}$ & $\begin{array}{l}.33^{* *} \\
.08 \\
.30^{* *} \\
.02\end{array}$ & $\begin{array}{l}-.65^{* *} \\
.02 \\
-.11 \\
.25^{* *}\end{array}$ & $\begin{array}{l}.25^{* *} \\
.35^{* *} \\
.62^{* *} \\
.36^{* *}\end{array}$ & $\begin{array}{l}-.58^{* *} \\
-.17 \\
-.12 \\
.16\end{array}$ & $\begin{array}{l}.16 \\
-.11 \\
.58^{* *} \\
.37^{* *}\end{array}$ & $\begin{array}{l}-.14 \\
-.12 \\
.32^{* *} \\
.46^{* *}\end{array}$ & $\begin{array}{l}.38^{* *} \\
.21^{*} \\
.21^{* *} \\
.11\end{array}$ & $\begin{array}{l}.27^{* *} \\
-.00 \\
.44^{* *} \\
.23\end{array}$ & $\begin{array}{l}.17 \\
-.13 \\
.09 \\
.09\end{array}$ & $\begin{array}{l}.13 \\
.48^{* *} \\
-.02 \\
.14\end{array}$ & $\begin{array}{l}(.89) \\
.07 \\
.15 \\
-.10\end{array}$ & $\begin{array}{l}(.72) \\
.11 \\
.15\end{array}$ & $\begin{array}{l}(.71) \\
.32^{* *}\end{array}$ & $(.54)$ \\
\hline
\end{tabular}

${ }^{\mathrm{a}}$ dummy coded $(1=$ more than 10 years, $0=$ less than 10 years $) .{ }^{b}$ dummy coded $(1=$ producer, $0=$ services, $0=$ manufacture $){ }^{C}$ dummy coded $(1=$ private

limited co., $0=$ proprietors, $0=$ partner, $0=$ limited co.). (nc) not calculated. Cronbach alpha is on the diagonal. ${ }^{*} p<.05 . * * p<.01$.

Table 4. Relationship between Entrepreneurial Orientation and Distinctive Capabilities

\begin{tabular}{|c|c|c|c|c|c|c|c|c|}
\hline COD & $\mathrm{P} / \mathrm{Dev}$ & Fin Inf & HR & $\mathrm{CS}$ & GA & $\mathrm{E} \mathrm{Mgt}$ & It & Eng \\
\hline \multicolumn{9}{|l|}{ Model 1} \\
\hline$R^{2}$ & .28 & .34 & .15 & .06 & .19 & .21 & .03 & .02 \\
\hline Adjusted $R^{2}$ & .26 & .32 & .13 & .03 & .17 & .19 & .01 & -.00 \\
\hline$F$ value & $15.68 * *$ & $20.25 * *$ & $7.05 * *$ & 2.40 & $9.43 * *$ & $10.61 * *$ & 1.23 & .87 \\
\hline \multicolumn{9}{|l|}{ Model 2} \\
\hline$R^{2}$ & .59 & .51 & .46 & .35 & .30 & .37 & .14 & .26 \\
\hline Adjusted $R^{2}$ & .57 & .48 & .42 & .32 & .26 & .33 & .08 & .22 \\
\hline$F$ value & $22.28 * *$ & $10.02 * *$ & $16.38 * *$ & $13.35^{* *}$ & $4.64 * *$ & $7.21 * *$ & $3.55 * *$ & $9.40 * *$ \\
\hline Durbin Watson & 1.92 & 1.27 & 1.87 & 1.46 & 2.09 & 1.70 & 1.85 & 1.53 \\
\hline \multicolumn{9}{|c|}{ Standardized $\beta$ Coefficient } \\
\hline \multicolumn{9}{|l|}{ Model 1} \\
\hline Age $(>10$ years $)$ & -.11 & $.26 * *$ & -.13 & .03 & $-.25 * *$ & -.14 & -.09 & .01 \\
\hline Producers & $-.49 * *$ & $.69 * *$ & -.21 & .12 & $-.40 * *$ & $-.41 * *$ & -.02 & -.10 \\
\hline Private Ltd. Co. & $.16 *$ & $.19 *$ & $.28 * *$ & .25 & .16 & $.17 *$ & .15 & .08 \\
\hline Model 2 & & & & & & & & .11 \\
\hline Com. Aggressiv & .01 & $-.35 * *$ & .07 & -.12 & $.40 * *$ & $.34 * *$ & $.32 * *$ & $.46 * *$ \\
\hline Proactive & $.24 * *$ & -.11 & $-.21 * *$ & -.19 & .10 & -.05 & -.14 & -.15 \\
\hline Risk Taking & $.43 * *$ & -.01 & $.45 * *$ & $.21 *$ & .12 & $.34 * *$ & .09 & .13 \\
\hline Innovative & $.22 * *$ & $.24 * *$ & $.26 * *$ & $.42 * *$ & .08 & .10 & $.20 *$ & \\
\hline
\end{tabular}

$\mathrm{COD}=$ Coefficient of Determination, P/Dev $=$ Process Development, Fin Inf $=$ Financial Information, HR $=$ Human resource, CS $=$ Capital structure, $\mathrm{GA}=$ General administration, $\mathrm{E} \mathrm{Mgt}=$ Entrepreneurial management, $\mathrm{It}=$ Information technology, Eng $=$ Engineering, $\quad * p<.05$, $* * p<.01$ 
Table 5. Relationship between Distinctive Capabilities and Return on Sales

\begin{tabular}{lll}
\hline Coefficient of Determination & Model 1 & Model 2 \\
\hline$R^{2}$ & .24 & .48 \\
Adjusted $R^{2}$ & .22 & .43 \\
$F$ value & $12.79 * *$ & $6.47^{* *}$ \\
Durbin Watson & 1.38 & 1.38 \\
\hline & Standardized $\beta$ Coefficient & \\
\hline Firm's Age (More than 10 years) & $\mathbf{. 3 4 * *}$ & \\
Producers & $\mathbf{. 4 8 * *}$ & \\
Private Limited Company & -.13 & .08 \\
\hline Process development & & $\mathbf{. 5 5 * *}$ \\
Financial information & & .08 \\
Human resources & & .02 \\
Capital structure & & -.13 \\
General administration & & $-.19 *$ \\
Entrepreneurship management & & -.13 \\
Information Technology & & -.08 \\
Engineering & & \\
\hline
\end{tabular}

$* p<.05, * * p<.01$

Table 6. EO-ROS Relationship Mediated by DC

\begin{tabular}{|c|c|c|c|}
\hline Coefficient of Determination & Model 1 & Model 2 & Model 3 \\
\hline$R^{2}$ & .24 & .51 & .55 \\
\hline Adjusted $R^{2}$ & .22 & .48 & .52 \\
\hline$F$ value & $12.79 * *$ & $16.18^{* *}$ & $10.15^{* *}$ \\
\hline Durbin Watson & 1.34 & 1.38 & .138 \\
\hline \multicolumn{4}{|l|}{ Standardized $\beta$ Coefficient } \\
\hline Firm age ( $>10$ years) & $.34 * *$ & $.22 * *$ & $.17^{*}$ \\
\hline Producers & $.48 * *$ & $.20^{*}$ & .06 \\
\hline Private Limited Company & -.13 & -.04 & -.11 \\
\hline Competitive Aggressiveness & & $-.53 * *$ & $-.43 * *$ \\
\hline Proactiveness & & .05 & .08 \\
\hline Risk Taking & & -.02 & -.02 \\
\hline Innovativeness & & $.21 * *$ & $.14^{*}$ \\
\hline Financial Information & & & $.28 * *$ \\
\hline
\end{tabular}




\section{Exhibit 1. Power Analysis}

The Effect Size (ES) $=f^{2}=R^{2} /\left(1-R^{2}\right)$

For EO and ROS (Refer Table 6 - Model 2)

$$
\begin{gathered}
R^{2}=.51 \\
f^{2}=(.26) /(1-.51) \\
=.53
\end{gathered}
$$

With $\mathrm{ES}=.53, \mathrm{~N}=125 \bumpeq 100$

Power=.94@ $@<.05$ or .82 @ $p<.01$ (Cohen et al., 2003; Hair et al., 1998).

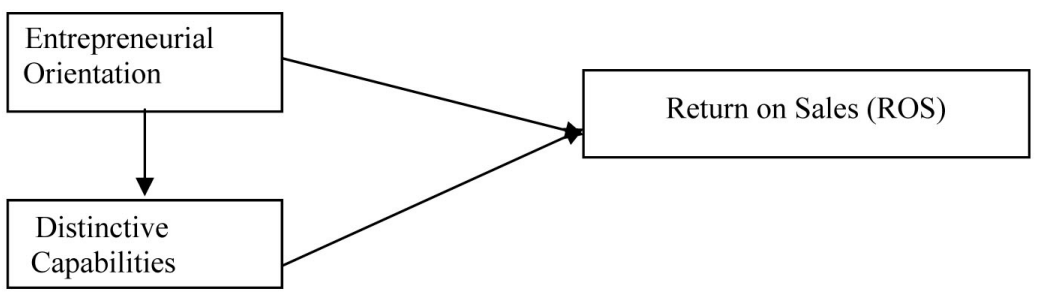

Figure 1. Theoretical Framework (Ex-ante).

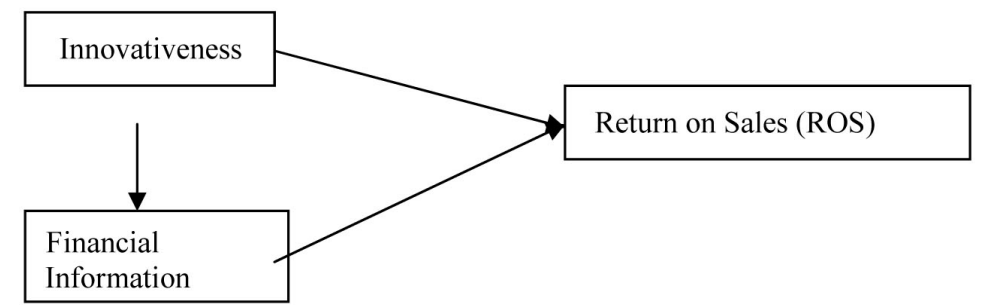

Figure 2. Theoretical Framework (Ex-post). 